\title{
Mapping a Nation: Daniel Carter Beard's Time as a Surveyor for the Sanborn Map Company
}

\author{
John J. Swab ${ }^{a^{*}}$ \\ a University of Kentucky,john.j.swab@uky.edu \\ * Corresponding author
}

Keywords: insurance mapping, Sanborn Map Company, surveying, company organization, lived experiences, Daniel Carter Beard, cartographic production

\begin{abstract}
:
Fire insurance maps produced by the American firm the Sanborn Map Company have long served as cartographic guides to understanding the history of urban America. Primarily used by cultural and historical geographers, historians, historic preservationists, and environmental consultants; historians of cartography have little explored the history of this company. While this scholarship has addressed various facets of Sanborn's history (Ristow, 1968), no scholarly piece has explored the lived experience of being a Sanborn surveyor. This lack of scholarship comes not from any significant oversight but rather from the fact that the contributions of most Sanborn surveyors were anonymous and little recorded on the maps themselves. Moreover, the company itself has done little to save its own history, thus little is known of their individual stories and experiences. The exception to this is perhaps the most famous Sanborn surveyor of all: Daniel Carter Beard.
\end{abstract}

Over the course of his nine-decade life, Daniel Carter Beard held several prominent positions including the co-founder of the Boy Scouts of America and the lead illustrator for many of Mark Twain's novels. However, he got his start as a surveyor for the Sanborn Map Company in the 1870s, just a few years after its founding. His papers, housed at the Manuscript Division of the Library of Congress, includes a variety of ephemera from his time with the Sanborn Map Company.

Trained in civil engineering, Beard got his start as a surveyor for the Cincinnati (Ohio) Office of Platting Commission, creating the first official plat map for the city. He was hired by Sanborn in 1874 and served as a surveyor until 1878, traveling extensively over the eastern half of the United States, parlaying his skills into creating fire insurance maps for Sanborn. Thus, this paper speaks to two main themes. The first theme traces the route of Beard during his early years with the company across the eastern half of the United States, documenting both the places he visited and the challenges he faced as a Sanborn surveyor. The second theme, interwoven through the paper, is an analysis of the innerworkings of Sanborn's administrative structure and its relationship with the larger fire insurance market during the 1870s. Altogether, these documents present unique insight into the organization of the Sanborn Map Company and how it produced its maps during the second-half of the $19^{\text {th }}$ century. 